Tô-râ: Volume 4 Nomor 2, Agustus 2018, Rospita A. Siregar, hal. 43-46

\title{
PENERAPAN UNDANG-UNDANG NOMOR 13 TAHUN 2006 \\ SEBAGAI BENTUK HUKUM YANG BERSIFAT RESPONSIF \\ (TINJAUAN KASUS PELECAHAN PASIEN OLEH SEORANG PERAWAT)
}

\author{
Oleh: Rospita A. Siregar \\ mapituki@yahoo.co.id \\ Universitas Kristen Indonesia, Jakarta, Indonesia
}

\begin{abstract}
The responsive nature of the law according to Philippe Nonet and Philip Selznick aims to achieve competence in order to obtain a sense of justice and meet the expectations of the community, not merely offering procedural justice but substantive justice. The formation of Law number 13 of 2006 concerning Protection of Witnesses and Victims (UUPSK) as a product of regulations that are subordinate to the principles and policies of the government was born as a form of rule of law in society. The results obtained from the testimony of witnesses and victims helped the prosecution of a case. Article 3 states that the protection of witnesses and victims is based on respect for human dignity, security, justice; non-discriminatory and legal certainty. The problem is when witnesses and victims provide information, fear and trauma arise to explain what happened, so that witnesses need protection for themselves and their families. In the case of the abuse of female patients by male nurses in hospitals in East Java, as a result of this unpleasant treatment, the victim's husband reported to the authorities, the victim's family demands a form of hope for law enforcement and subsequently obtained justice and legal certainty. The legal process to determine whether a claim is proven in the form of a violation of the law, then there are two elements that must be ful lled namely: the actus reus element or the essential element of crime and mens rea (mental element).
\end{abstract}

Keyword : legal certainty; UUPSK; non-discriminatory; violation of the law.

\section{Pendahuluan}

Pertimbangan lahirnya Undang Undang nomor 13 tahun 2006 tentang perlindungan saksi dan korban, beberapa diantaranya : bahwa salah satu alat bukti yang sah dalam proses peradilan pidana adalah

keterangan Saksi dan/atau Korban yang mendengar, melihat, atau mengalamisendiri terjadinya suatu tindak pidana dalam upaya mencari dan menemukankejelasan tentang tindak pidana yang dilakukan oleh pelaku tindak pidana;b. bahwa penegak hukum dalam mencari dan menemukan kejelasan tentangtindak pidana yang dilakukan oleh pelaku tindak pidana sering mengalamikesulitan karena tidak dapat menghadirkan Saksi dan/atau Korban disebabkanadanya ancaman, baik fisik maupun psikis dari pihak tertentu;c. bahwa sehubungan dengan hal tersebut, perlu dilakukan perlindungan bagiSaksi dan/atau Korban yang sangat penting keberadaannya dalam prosesperadilan pidana. ${ }^{1}$

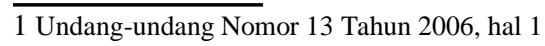

Di beberapa kasus yang pelakunya masih ada hubungan keluarga, maka pembuktian berupa kesaksian korban sangat sukar didapat.Sudah dijelaskan diatas bahwa kesaksian saksi dan korban adalah instrumen yang tepat dalam memenuhi ketentuan hukum dimana dapat ditetapkan sanksi, dalam hukum pidana, yang bertujuan retributif. ${ }^{2}$

Dalam kasus pelecahan pasien oleh seorang perawat di rumah sakit swasta wilayah Jawa Timur diperoleh data bahwabermula ketika korban pasca operasi dipindahkan dari ruang opearsi ke ruang pemulihan, datang perawat pria melakukan tindakan yang tidak terpuji,lalu kasus ini dilaporkan oleh suami korban ke sentra pelayanan kepolisian terpadu (SPKT) Polrestabes setempat kamis 25 Januari 2018. Fakta sosial yang terjadi berdasarkan penuturan korban saat itu terjadi sikap dan tindakan pelecehan seksual atas klien nya, secara sadar korban mengetahui bahwa paramedis melakukan namun korban tak berdaya. akibat

\footnotetext{
2 Jimly Asshiddiqie, Ali Safa'at, Teori Hans Kelsen tentang Hukum, Ja-
} karta, Konstitusi Press, 2006. Hal 46 
perlakuan asusila yang terjadi, korban mengalamai gangguan kejiwaan .

Dilihat dari perbuatan perawat dapat disebut sebagai pelaku delik, yang artinya individu yang perbuatannya keluar dari tatanan/aturan hukum, dapat diberikan sanksi. Dalam teori hukum pidana tradisional, terdapat perbedaan antara mala in se dan mala in prohibita. Mala in se adalah tindakan yang jahat karena tindakan itu sendiri (evill in itself), sedangkan mala in prohibita adalah tindakan yang disebut jahat karena dilarang oleh tata hukum positif, ${ }^{3}$ dalam hukum perdata sanksi ditujukan kepada pihak lain yang menyebabkan kerugian, deliknya terpenuhi kewajibannya membayar ganti rugi, orang yang bertanggungjawab terhadap sanksi mampu menghindari sanksi melalui perbuatan yang semestinya, yakni dengan memberikan ganti rugi atas kerugian yang disebabkan oleh seorang lain. ${ }^{4}$

\section{Permasalahan}

Bagaimana menerapkan Undang Undang Nomor 13 tahun 2016 tentang perlindungan saksi dan korban, sebagai dasar pihak korban maupun saksi mengungkapkan kronologis kejadian yang sebenarnya tanpa rasa takut, contoh yang diambil ialah kasus pelecehan seksual pasien perempuan yang dirawat di rumah sakit swasta di Jawa Timur?

\section{Tujuan Penulisan}

Mengetahui efektivitas penerapan Undang Undang Nomor 13 tahun 2016 tentang perlindungan saksi dan korban, sebagai dasar pihak korban maupun saksi mengungkapkan kronologis kejadian yang sebenarnya tanpa rasa takut, dalam hal ini pada kasus pelecehan seksual pasien perempuan yang dirawat di rumah sakit swasta di Jawa Timur.

\section{Pembahasan}

Pendapat Pakar hukum Philippe Nonet menitik beratkan kepada tipe hukum yang bertumpu pada Sociological Jurisprudence, juga ditujukan untuk memberi kemampuan bagi institusi hukum, sehingga dalam fakta sosial ${ }^{5}$, hukum dapat berproses dan berimplikasi

3 ibid, hal 47

4 Hans Kelsen, General theory Of Law and State, New York: Russell \& Russel, 1961 hal 102

5 Philippe Nonet, Philip Selznick : Hukum Responsif, Nusa Media, Bandung,2015, hal 83 dengan baik, dalam kasus pelecahan seksual pasien perempuan yang terjadi di rumah sakit swasta di Jawa timur ,fakta sosial nya adalah korban dirugikan akibat tindakan tak terpuji dari perawat pria tersebut, bila proses hukum berjalan dengan benar dan berimplikasi maka pemeriksaan korban dan saksi harus di jalankan dengan merujuk kepada UUPSK.

Philippe mengharapkan fakta sosial yang ada di masyarakat dapat mendorong terjadinya proses hukum dan institusi melakukan upaya hukum sebagai implikasi hukum itu sendiri, namun kenyataan sangat banyak ditemukan rasa takut dan tertekan apabila pemeriksaan bagi saksi dan korban dalam suatu perkara, keengganan untuk ungkap data sering terjadi, walau dalam tulisan ini tidak di cermati secara khusus.kasus demi kasus seringkali tidak dapat terungkap secara jelas, tapi sudah dimuat dalam media sosial, hal semacam ini sebenarnya merugikan dan merongrong wibawa institusi hukum.

Dalam kasus pelecehan seksual pasien perempuan yang dirawat di rumah sakit swasta berlokasi di Jawa Timur, memicu banyak penilaian di berbagai pihak, sikapperawat pria yang tidak terpuji dapat di kaji berdasarkan pasal 28 Undang Undang nomor 38 tahun 2014 tentang keperawatan, ${ }^{6}$ menyebutkan bahwa hak seorang perawat ialah melakukan perawatan di fasilitas pelayanan kesehatan atau mandiri harus berdasarkan pada kode etik, standar pelayanan, standar profesi, dan standar prosedur operasional. Praktik keperawatan sebagaimana dimaksud didasarkan pada prinsip kebutuhan pelayanan kesehatan dan/atau keperawatan masyarakat dalam suatu wilayah.Hak seorang perawat antara lain menolak keinginan penerima pelayanan kesehatan atau pihak lain yang bertentangan dengan standar profesi, kode etik, standar pelayanan, standar prosedur operasional, atau ketentuan peraturan perundang-undangan sesuai pasal 57Undang Undang nomor 36 tahun 2014 tentang tenaga kesehatan, ${ }^{7}$ sedangkan dalam pasal 60 tenaga kesehatan memberi pelayanan sesuai dengan bidang keilmuan yang dimiliki , bersikap dan berperilaku sesuai dengan etika profesi, bekerja berdasarkan standar profesi diatur dalam pasal 66 , layanan diluar kewenangannya diatur dalam 6 Undang Undang nomor 38 tahun 2014 tentang keperawatan, hal 18 7 Undang undang nomor 36 tahun 2014 tentang tenaga kesehatan, hal 19-20 
pasal 63 untuk melakukan tindakan medic diatur dalam pasal 31 Undang Undang nomor 38 tahun 2014 tentang keperawatan. ${ }^{8}$

Mengenai kewenangan tenaga perawat diuraikan dalam Pasal 29 Undang undang nomor38 tahun 2014 disebutkan bahwa, dalam praktik keperawatan, perawat menyelenggarakan berbagai tugas sebagai pemberi asuhan keperawatan, penyuluh dan konselor bagi klien, pelaksana tugas berdasarkan pelimpahan wewenang yang dilaksanakan secara bertanggung jawab dan akuntabel dapat dilakukan bersama-sama ataupun sendiri-sendiri. ${ }^{9}$ Pada pasal 58 dan 59 undang undang nomor 36 tahun 2014 kewajiban perawat ialahmemberikan pelayanan kesehatan sesuai dengan standar profesi, standar pelayanan profesi, standar prosedur operasional, dan etika profesi serta kebutuhan kesehatan penerima pelayanan kesehatan pada keadaan gawat darurat dan/ataupada bencana untuk penyelamatan nyawa dan pencegahan kecacatan.

Sehingga perbuatantenaga kesehatan dalam kasus pelecahan terhadap klien nya di rumah sakit swasta di wilayah Jawa Timur menurut pasal 82 Undang Undang nomor 36 tahun 2014 tentang tenaga kesehatan menurut ayat 1 (satu) yang berbunyi : setiap tenaga kesehatan yang tidak melaksanakan ketentuan Pasal 47, pasal 52 ayat (1), Pasal 54 ayat (1), Pasal 58 ayat (1), Pasal 59 ayat (1), Pasal 62 ayat (1), Pasal 66 ayat (1), Pasal 68 ayat (1), Pasal 70 ayat (1), Pasal 70 ayat (2), Pasal 70 ayat (3) dan Pasal 73 ayat (1) dapat dikenai sanksi administratif. Ayat 4(empat) menyatakan bahwa sanksi administratif sebagaimana dimaksud dapat berupa: teguran lisan; peringatan tertulis; denda administratif; dan/atau pencabutan izin. Tata cara pengenaan sanksi administratif terhadap tenaga kesehatan dan fasilitas pelayanan diatur dengan Peraturan Pemerintah.Apabila keterangan saksi dan korban dapat diperoleh dan merujuk kepada perbuatan tidak terpuji seorang perawat maka ${ }^{10}$

Maka ketika paramedis dalam kesadaran penuhsengaja melakukan tindakan pelecehan seksual bagi klien nya sudah jelas melanggar peraturan yang berlaku, dalam pasal 84 UU nomor 36 tahun 2014

\footnotetext{
8 lo,cit, hal 21

9 lo.cit hal 19

10 Undang Undang nomor 36 tahun 2014 tentang tenaga kesehatan, hal 25
}

ayat 1(satu) tertulis Setiap Tenaga Kesehatan yang melakukan kelalaian berat yang mengakibatkan Penerima PelayananKesehatan luka berat dipidana dengan pidana penjara paling lama 3 (tiga) tahun. Ayat (2) Jika kelalaian berat sebagaimana dimaksud pada ayat (1) mengakibatkan kematian, setiap TenagaKesehatan dipidana dengan pidana penjara paling lama 5 (lima) tahun. ${ }^{11}$ Dalam kasus pelecehan pasien ini telah berdampak ke psikis pasien, dampak psikis ini sukar di kategorikan derajat kesakitannya, oleh sebab itu pendapat Psikiater dimintakan sebagai dasar pertimbangan putusan.

Kedudukan saksi dan kedudukan korban bila memberikan informasi lengkap dan jelas di suatu perkara, maka tidak sulit untuk menganalisa perkara itu, bahkan dengan waktu cukup singkat tercapai posisi kasus yang secara "terang benderang" . hasil pemeriksaan saksi dan korban dalam kasus ini,dapat menetapkan apakah perawat bersalah atau tidak, sesuai Pasal 1(satu) KUHPidanayang berbunyi : (1) Suatu perbuatan tidak dapat dipidana, kecuali berdasarkan kekuatan ketentuan perundang-undangan pidana yang telah ada, (2) Bilamana ada perubahan dalam perundang-undangan sesudah perbuatan dilakukan, maka terhadap terdakwa diterapkan ketentuan yang paling menguntungkannya. ${ }^{12}$

Lembaga perlindungan saksi dan korban adalah lembaga mandiri yang didirikan dan bertanggung jawab untuk memberikan perlindungan dan bantuan pada saksi dan korban berdasarkan tugas dan kewenangan sebagaimana diatur dalam Undang-Undang nomor 13 tahun 2006 pasal 1(satu) angka 3(tiga)dimana terakomodir semua hak-hak saksi dan korban dalam proses peradilan pidana.

\section{Kesimpulan}

Penerapan Undang Undang nomor 13 tahun 2006 tentang Perlindungan Saksi dan Korban bagi masyarakat yang menjadi saksi dan maupun seba- gai korban dalam satu perkara hukum, merasakan adanya payung hukum bagi dirinya, dan adanya kepastian hukum dalam sistem peradilan di Indonesia, Masyarakat menyadari banyaknya faktor eksternal yang mengganggu implementasi Undang undang ini 11ibid. hal 26 12 KUH Pidana (WETBOEK VAN STRAFRECHT) 
misalnya rasa ketakutan dan tekanan lain yang datang dari pihak tersangka, belum lepas dari perasaan malu, dampak media publik. Budaya mengalah menerima dan rasa ikhlas akan sebuah suratan takdir mungkin lebih mendominasi .Maka disarankan LPSK ditingkat pemerintahan dapat menjalankan fungsi dengan baik, bebas dari pengaruh Kolusi dan Nepotisme, mampu menempatkan pihak yang salah pada tempatnya.

Undang Undang nomor 13 tahun 2006 tentang Per- lindungan Saksi dan Korban merupakan sifat hukum yang bersifat responsif, dengan terpenuhinya karakter responsif yang memiliki ciri khas yaitu mencari nilai- nilai yang tersirat implicit value. 
Tô-râ: Volume 4 Nomor 2, Agustus 2018, Rospita A. Siregar, hal. 43-46

\section{Daftar Pustaka}

Jimly Asshiddiqie, Ali Safa'at, Teori Hans Kelsen tentang Hukum, Konstitusi Press, Jakarta, 2006

Hans Kelsen, Teori Tentang Hukum,Konstitusi Press,Jakarta,2012

Hans Kelsen, General theory Of Law and State, New York: Russell \& Russel, 1961

Aan Efendi,Freddy Poernomo,IG.NG IndraS.Ranuh, Teori Hukum,Sinar Grafika,Jakarta 2016

Philippe Nonet, Philip Selznick : Hukum Responsif, Nusa Media, Bandung,2015

Satjipto Rahardjo, Teori Hukum,Genta Publishing,Yogyakarta,2013

KUH Pidana (WETBOEK VAN STRAFRECHT)

Undang-Undang No. 13 Tahun 2006 tentang Perlind- ungan Saksi dan Korban

Undang Undang Nomor 38 tahun 2014 tentang kep- erawatan

Undang-Undang Nomor 36 tahun 2014 tentang tenaga Kesehatan 